\title{
DUKUNGAN KELUARGA TERHADAP KEKAMBUHAN PASIEN GANGGUAN JIWA DI RUMAH SAKIT JIWA PROF. Dr.SOEROYO DI MAGELANG
}

\author{
FAMILY SUPPORT RELATIONSHIP TO RECURRENCE OF MENTAL \\ DISORDERS PATIENTS AT PROF. Dr. SOEROYO HOSPITASL \\ IN MAGELANG \\ A.Gani
}

Prodi Keperawatan Lahat Poltekkes Kemenkes Palembang, Sumatera Selatan, Indonesia (email penulis korespondensi: abdulgani146@gmail.com)

\author{
Info Artikel: Diterima: 02 April $2019 \quad$ Revisi: 30 April $2019 \quad$ Diterima: 31 Mei 2019
}

\begin{abstract}
ABSTRAK
Latar belakang : Krisis multi dimensi yang terjadi di Indonesia berpengaruh pada peningkatan kekambuhan penderita gangguan jiwa. Penelitian ini bertujuan menganalisi dukungan keluarga terhadap kekambuhan paisen gangguan jiwa di rumah sakit jiwa Prof. Soeroyo.

Metode : Jenis penelitian ini menggunakan desain studi korelasional dengan pendekatan cross sectional. Jumlah sampel 78 responden, sambel diambil dengan teknik porpusive sample. Instrumen yang digunakan adalah kuesioner dukungan keluarga dan kuesioner observasi kekambuhan. Analisis yang digunakan uji non parametric.

Hasil : Dari hasil univariat karakteristik klien gangguan jiwa yaitu umur : 15-24 tahun 32 responden $(41,0 \%)$, jenis kelamin : laki-laki 46 responden $(59,9 \%)$, pendidikan : SD 34 responden $(43,6 \%)$, frekuensi opname : 2 kali 38 responden $(48,7 \%)$, karakteristik keluarga klien gangguan jiwa yaitu Jenis kelamin laki-laki 47 responden (60,3\%), umur : 41-50 tahun 34 responden (43,6\%), pendidikan : SD 34 responden $(34,6 \%)$, hubungan dengan klien : orang tua 38 responden $(48,7 \%)$, tingkat dukungan keluarga klien gangguan jiwa : sedang 40 responden $(51,3 \%)$, tingkat kekambuhan klien gangguan jiwa: sedang 50 responden $(64,1 \%)$. Dari hasil bivariat terdapat hubungan yang signifikan antara dukungan keluarga dan kekambuhan klien gangguan jiwa. Dengan nilai Correlation Coefficien $-.177(\mathrm{pv}=0,027)$.
\end{abstract}

Kesimpulan : Kekambuhan klien gangguan jiwa sangat tergantung dengan dukungan keluarga, karena itu peran keluarga dalam mendukung klien gangguan jiwa harus ditiingkatkan.

Kata kunci : Dukungan, Keluarga, Kekambuhan

\begin{abstract}
Background: The aimed of this study was to analyze family support relationship to recurrence of mental disorders patients.
\end{abstract}

Methods: This type of research uses a correlational study design with cross sectional approach. The number of samples was 78 respondents. Sampling with porpusive sample technique. The instruments used were the family support questionnaire and the recurrence observation questionnaire. The analysis used non-parametric test.

Results: characteristics of mental disorders clients that are age: 15-24 years 32 respondents (41.0\%), gender: 46 respondents (59.9\%), education: 34 respondents (43.6\%)), frequency of hospitalization: 2 times 38 respondents (48.7\%), mental family characteristics of the client, namely male sex 47 respondents (60.3\%), age: $41-50$ years 34 respondents $(43.6 \%)$, education: elementary school 34 respondents (34.6\%), relationship with clients: parents 38 respondents $(48.7 \%)$, family support level of mental illness clients: 40 respondents $(51.3 \%)$, recurrence rate of mental disorders clients : while 50 respondents (64.1\%), from the Bivariate results there was a significant relationship between family support and recurrence of mental illness clients, the Correlation Coefficient value -1777 ( $p v=0.027)$. Conclusion: There is a significant relationship between family support and recurrence of mental illness clients. Relationships are negative which means the higher the family support, the lower the level of client recurrence.

Keywords: Family Support, Recurrence of Mental Disorders, Hospital 


\section{PENDAHULUAN}

Penanganan psikologis saat ini telah mampu Pengobatan psikiatri saat ini telah mampu meminimalisasi disfungsi pada gangguan jiwa, sistem pelayanan kesehatan untuk pasien gangguan jiwa di Indonesia juga sudah lebih baik, kedua faktor positif ini tidak akan bermanfaat jika pasien dan keluarga tidak memanfaatkannya dengan optimal (Dharmady, 2001) ${ }^{1}$. Sebagian besar kegagalan pengobatan dan perawatan gangguan jiwa disebabkan oleh rendahnya dukungan dan kepedulian keluarga (68\% dari 303 pasien dirawat inap di RSJP.Prof.Dr.Soeroyo Magelang per September 2009 tidak dipedulikan keluarganya), hal tersebut ditandai dengan rendahnya pengetahuan tentang tanda-tanda dari kelainan jiwa dan cara penanggulangannya. 1999). ${ }^{2}$

Ekspresi emosi merupakan sikap keluarga terhadap penderita gangguan jiwa yang ditunjukkan baik secara verbal maupun nonverbal yang berisi komentar kritis, seperti memarahi, mengkritik, mencela, menghina dan keterlibatan emosional yang berlebihan, seperti terlalu melindungi, mengatur, atau membatasi. Ekspresi emosi seperti ini dapat meningkatkan resiko kekambuhan pada penderita gangguan jiwa dan akan menambah disability bagi penderitanya sehingga akan menjadi beban keluarga ${ }^{3}$.

Untuk mencegah terus masalah kesehatan yang berkaitan dengan gangguan kesehatan jiwa pada anggota keluarga perlu dilakukan pemberdayaan dan peningkatan keluarga karena keluarga merupakan unit yang paling dekat dengan klien, efektifitas suatu pengobatan dan keberhasilan perawatan di rumah sakit selain dipengaruhi oleh kualitas pelayanan kesehatan, sikap serta ketrampilan petugasnya juga dipengaruhi oleh lingkungan, sikap dan pola hidup pasien dan keluarganya. Selain itu juga

\section{METODE PENELITIAN.}

Jenis penelitian yang dilakukan adalah penelitian cross sectional. Penelitian dilaksanakan di Poliklinik RSJP.Prof.Dr.Soeroyo Magelang. Adapun jumlah sampel sebanyak 78 responden, dipengaruhi oleh kerjasama yang positif antara petugas kesehatan dan keluarganya. Apabila pasien dan keluarganya mempunyai pengetahuan tentang cara-cara penyembuhan dan pencegahan penyakit serta mampu berpartisipasi secara positif sejak awal dirawat dirumah sakit hingga perawatan di rumah maka hal ini dapat membantu penyembuhan dan mencegah kekambuhan pasien yang bersangkutan. ${ }^{14}$

Pentingnya dukungan keluarga dalam perawatan klien gangguan jiwa dapat dipandang dari berbagai segi : 1) Keluarga merupakan tempat individu memulai hubungan interpersonal dengan lingkungannya. Keluarga merupakan institusi pendidikan utama bagi individu untuk belajar dan mengembangkan nilai, keyakinan, sikap dan perilaku. 2) Jika keluarga dipandang sebagai suatu sistem maka gangguan yang terjadi pada satu anggota keluarga dapat mempengaruhi seluruh sistem. 3) Berbagai pelayanan kesehatan jiwa bukan klien seumur hidup tetapi hanya fasilitas pembantu klien dan keluarga mengembangkan kemampuan dalam mencegah terjadinya masalah, menanggulangi berbagai masalah dan mempertahankan keadaan adaptif. 4) Beberapa penelitian menyebabkan bahwa salah satu penyebab kambuhnya gangguan jiwa adalah keluarga yang tidak tahu cara menangani perilaku klien dirumah. ${ }^{4}$

Pasien jiwa sering mengalami kekambuhan. Hal ini disebabkan karena pengobatan yang terhenti dan peran serta keluarga dalam merawat penderita gangguan jiwa. Pernyataan diatas menunjukan bahwa keluarga berperan penting dalam proses terjadinya kekambuhan. Fenomena ini dapat dilihat dari banyaknya pasien gangguan jiwa yang sudah sembuh dan dipulangkan untuk perawatan di rumah kembali lagi atau terjadi kekambuhan. ${ }^{5}$

Selanjutnya data yang telah dikumpulkan diolah dan dianalisis yang terdiri dari univariat dan bivariat. Pada analisis bivariat menggunakan uji statistic correlation Non Product Moment. ${ }^{8,9,10,11,12}$ 


\section{HASIL}

Berdasarkan Tabel 1. diketahui bahwa dari 78 keluarga klien gangguan jiwa, yaitu jenis kelamin mayoritas laki-laki yaitu 47 responden $(60,3 \%)$. Umur mayoritas 41 - 50 tahun $(43,6 \%)$. pendidikan mayoritas SD adalah 27 responden (72,1\%). hubungan responden dengan klien mayoritas orang tua adalah 38 responden $(48,7 \%)$, tingkat dukungan keluarga mayoritas sedang adalah 40 responden $(51,3 \%)$,

Tabel 1. Hasil Analisa Univariat Karakteristik Keluarga Klien Gangguan Jiwa Di PoliklinikRSJP.Prof. Dr. Soeroyo Magelang $(n=78)$

\begin{tabular}{lcc}
\hline Variabel & Jumlah & Presentase \\
\hline Jenis kelamin & 47 & 60.3 \\
1. Laki - laki & 31 & 39.7 \\
2. Perempuan & & \\
Umur & 11 & 14.1 \\
1. $20-30$ tahun & 15 & 19.2 \\
2. $31-40$ tahun & 34 & 43.6 \\
3. $41-50$ tahun & 10 & 12.8 \\
4. $51-60$ tahun & 8 & 10.3 \\
5. 61 tahun keatas & & \\
& & \\
Pendidikan & 27 & 34.6 \\
1. SD & 24 & 30.7 \\
2. SLTP & 19 & 24.4 \\
3. SLTA & 8 & 10.3 \\
4. PT & & \\
Hubungan dengan klien & & 48.7 \\
1. Orang tua & 38 & 28.2 \\
2. Anak & 22 & 23.1 \\
3. Saudara & 18 & \\
Tingkat dukungan & & 29,5 \\
1. Rendah & 23 & 19,2 \\
2. Sedang & 40 & \\
3. Tinggi & & \\
\end{tabular}

Berdasarkan Tabel 2. diketahui bahwa dari 78 klien gangguan jiwa, yaitu umur mayoritas 15 24 tahun yaitu 32 responden $(41.0 \%)$. jenis kelamin mayoritas laki - laki adalah 46 responden $(59,9 \%)$. pendidikan mayoritas SD adalah 34 responden $(43,6 \%)$. Frekuensi opname klien mayoritas 2 kali adalah 38 responden $(48,7 \%)$. tingkat kekambuhan mayoritas sedang adalah 50 responden $(64,1 \%)$. 
Tabel 2. Dukungan Keluarga dengan Kekambuhan Klien Gangguan Jiwa

\begin{tabular}{lcc}
\hline Hasil Statistik & Dukungan & Kekambuhan \\
\hline Mean & 32.67 & 28.23 \\
Median & 31.00 & 26.50 \\
Mode & 17 & 42 \\
Std. Deviation & 13.269 & 10.525 \\
\hline
\end{tabular}

Tabel 2 diatas menunjukan bahwa nilai rata-rata atau mean dukungan yang dilakukan keluarga 32.67 yang berarti rata-rata dukungan yang dilakukan keluarga terhadap klien gangguan jiwa adalah dukungan dalam tingkat sedang (dukungan sedang nilai skor $21-47$ poin).
Sedangkan nilai mean kekambuhan klien 28.23 yang berarti rata-rata penderita gangguan jiwa yang datang berobat dalam tingkat kekambuhan sedang (kekambuhan sedang nilai skor $19-41$ poin).

Tabel 3. Hubungan Dukungan Keluarga dengan Kekambuhan Klien Gangguan Jiwa

\begin{tabular}{clcc} 
Hasil Statistik & & Dukungan & Kekambuhan \\
\hline Dukungan & Correlation Coefficient & 1.000 & $-.177^{*}$ \\
& Sig. (2-tailed) & 78 & .027 \\
& $\mathrm{~N}$ & & 78 \\
Kekabuhan & Correlation Coefficient & $-.177^{*}$ & 1.000 \\
& Sig. (2-tailed) & .027 &. \\
& $\mathrm{~N}$ & 78 & 78 \\
\hline
\end{tabular}

Tabel 3 diatas menunjukkan bahwa terdapat hubungan antara dukungan keluarga dan kekambuhan klien gangguan jiwa yang datang untuk berobat dengan nilai Correlation Coefficient $-.117^{*}$. Nilai ini bersifat negatif artinya

\section{PEMBAHASAN}

Berdasarkan hasil penelitian diketahui bahwa dari 78 responden, keluarga klien gangguan jiwa Di Poliklinik RSJP.Prof. Dr. Soeroyo Magelang. laki-laki 47 responden $(60.3 \%)$ dan perempuan 25 responden $(39.7 \%)$. Jumlah responden laki-laki lebih banyak dibanding dengan perempuan, hal ini sesuai dengan pernyataan bahwa laki-laki yang keluarganya menderita gangguan jiwa lebih bisa terbuka dalam mengungkapkan permasalahan dari pada wanita. ${ }^{14}$ Menurut pengamatan peneliti jumlah laki-laki lebih banyak disebabkan karena keluarga lebih merasa aman apabila klien datang berobat ditemani laki-laki. apabila dukungan keluarga tinggi maka kekambuhan klien dalam keadaan sebaliknya atau dalam keadaan rendah. Nilai signifikansi 0.027 ini berarti hubungan yang terjadi bersifat signifikan karena nilai 0.027 lebih kecil dari 0.05 sebagai nilai batas signifikasi.
Berdasarkan hasil penelitian diketahui bahwa dari 78 responden, keluarga klien gangguan jiwa Di Poliklinik RSJP.Prof. Dr. Soeroyo Magelang. 41 - 50 tahun 34 reponden (43.6\%). Responden keluarga dalam usia ini lebih memiliki kemampuan ekonomi yang mapan serta kepedulian terhadap klien gangguan jiwa. Hal tersebut sesuai dengan pernyataan bahwa kemapanan ekonomi keluarga berpengaruh terhadap cara/perlakuan keluarga terhadap penderita penyakit jiwa. ${ }^{2}$ 
Hal ini sesuai dengan peryataan bahwa penderita gangguan jiwa lebih banyak ditemukan pada keluarga dengan pendidikan dan sosial ekonomi yang rendah. ${ }^{14}$ Menurut pengamatan peneliti rendahnya pendidikan keluarga berakibat pada sulitnya mendapat pekerjaan yang layak yang berimbas pada rendahnya pendapatan keluarga untuk memenuhi segala kebutuhan, hal ini merupakan pemicu utama stresor yang berakibat terjadinya gangguan jiwa.

telah mengalami peningkatan. Menurut pengamatan peneliti meningkatnya dukungan keluarga ini diakibatkan karena informasi tentang kasehatan jiwa yang lebih mudah didapat karena adanya program-program rumah sakit jiwa yang terintegerasi langsung dengan Puskesmas dan sosialisasi tentang penyakit jiwa pada sekolah-sekolah serta penerimaan keluarga kepada anggota yang menderita gangguan jiwa semakin baik yang dibuktikan dengan kesadaran keluarga secara rutin datang untuk mengantar dan menemani klien gangguan jiwa untuk periksa/kontrol.

Berdasarkan hasil penelitian diketahui bahwa dari 78 responden, klien gangguan jiwa Di Poliklinik RSJP.Prof. Dr. Soeroyo Magelang. Jenis kelamin laki-laki 46 reponden $(59,9 \%)$. Keadaan ini sesuai dengan data yang ada pada medical record RSJ Dr. Ernaldi Bahar Palembang yaitu pasien yang dirawat hingga bulan november 2007 terdiri dari $64.8 \%$ lakilaki dan $35.2 \%$ perempuan tetapi hal tersebut tidak sesuai dengan pene, yang mengatakan bahwa wanita lebih mempunyai resiko terkena gangguan jiwa. Ketidak sesuaian ini menurut peneliti disebabkan karena keluarga yang mempunyai penderita gangguan jiwa wanita cenderung menyembunyikanya sehingga jarang penderita wanita yang datang untuk berobat. ${ }^{15}$

Berdasarkan hasil penelitian diketahui bahwa dari 78 responden, klien gangguan jiwa Di Poliklinik RSJP.Prof. Dr. Soeroyo Magelang. Umur 15-24 tahun 32 reponden (41,0\%).Hal ini sesuai dengan pendapat bahwa gangguan yang

\section{KESIMPULAN DAN SARAN}

Berdasarkan hasil penelitian dan pembahasan yang telah diuraikan sebelumnya, diketahui bahwa terdapat hubungan bermakna antara
Berdasarkan hasil penelitian diketahui bahwa dari 78 responden, keluarga klien gangguan jiwa Di Poliklinik RSJP.Prof. Dr. Soeroyo Magelang. hubungan responden dengan klien yaitu orang tua 38 reponden $(48,7 \%)$. Menurut pengamatan peneliti hal ini dikarenakan adanya rasa tanggung jawab emosional yang kuat kepada anak dari pada seorang anak terhadap orang tua dan seorang saudara yang saudara menderita penyakit jiwa.

$\begin{array}{llr}\text { Dukungan yang dilakukan } & \begin{array}{r}\text { keluarga } \\ \text { belum }\end{array}\end{array}$
sering terjadi pada dewasa muda dan remaja adalah ketidak mampuan memilih karir, mengembangkan tata nilai, atau menjalin hubungan erat. Rasa kohesif diri tak ada sehingga terjadi gangguan sosial dan pekerjaan. Hal ini merupakan pemicu gangguan jiwa. ${ }^{15}$

Berdasarkan hasil penelitian diketahui bahwa dari 78 responden, klien gangguan jiwa Di Poliklinik RSJP.Prof. Dr. Soeroyo Magelang. Pendidikan SD 34 reponden $(43,3 \%)$. Hal ini sesuai dengan pernyataan bahwa tinggi rendahnya pendidikan/pengetahuan seorang penderita gangguan jiwa berpengaruh terhadap cara pencegahan kekambuhan diri (Wahyudi, 2005). Menurut pengamatan peneliti pasien yang berpendidikan rendah lebih sulit menerima atau memahami pendidikan kesehatan yang diberikan oleh petugas kesehatan sehingga kekambuhan mudah terjadi.

Berdasarkan hasil penelitian diketahui bahwa dari 78 responden, klien gangguan jiwa Di Poliklinik RSJP.Prof. Dr. Soeroyo Magelang. Frekuensi opname yaitu 2 kali 38 reponden $(48,7 \%)$. Hal ini sesuai dengan pernyataan bahwa kekambuhan pertama setelah pasien sembuh akan lebih mudah terjadi karena perbedaan adaptasi di rumah sakit dan dilingkungan tempat tinggal yang jauh berbeda maka diperlukan dukungan keluarga untuk mengatasinya. Berdasarkan hasil penelitian diketahui bahwa dari 78 responden, klien gangguan jiwa Di Poliklinik RSJP.Prof. Dr. Soeroyo Magelang. Tingkat kekambuhan yaitu sedang 50 reponden $(60,4 \%)$.

dukungan keluarga dengan kekambuhan pasien dengan gangguan jiwa di Poliklinik Poliklinik RSJP.Prof. Dr. Soeroyo Magelang 
Oleh karena itu dukungan keluarga sangat diperlukan dalam mencegah kekambuhan klien gangguan jiwa Keluarga juga diharapkan meningkatkan informasi misalnya tentang

\section{UCAPAN TERIMAKASIH}

Teimakasih kami sampaikan kepada RSJP.Prof. Dr. Soeroyo Magelang dan semua pihak yang telah membantu dalam penyelesai penelitian ini.

\section{DAFTAR PUSTAKA.}

1. Dharmady, A. 2001. Fakto-faktor yang mempengaruhi pasien skizofrenia dalam pemilihan jalur pelayanan kesehatan jiwa pertama kali dan keterlambatan kontak ke fasilitas pelayanan kesehatan jiwa, Semarang:Konggres IDAJI (1)

2. Lisdarwati, Choirunisa, \& Rosyati. 1999. Peran kepedulian keluarga untuk mempercepat penyembuhan pasienrawat inap di RSJ Palembang. Jurnal bina Diknakes, 32.(2)

3. Keliat, B.A., Kobong, B.M., Suci, E.S., Hutagalung, E.A., Agiananda, F., Fausiah, F., Irmansyah, Sugiyanto, P.R., dan Gunawan, S., (2006). Menanti empati terhadap orang dengan gangguan jiwa. (Cetakan I). Jakarta: Pusat Kajian Bencana \& Tindak Kekerasan Departemen Psikiatri FKUI-RSCM.(3)

4. Rasmun, 2001. Keperawatan kesehatan mental psikiatri Terintegrasi dengan keluarga, Edisi 1. Penerbit: Sagung Seto, Jakarta(4)

5. Sukardi, 2002. Hubungan dukungan keluarga terhadap frekuensi kekambuhan penderita skizoprenia. Karya Tulis FK. UGM. Yogyakarta. Tidak dipublikasikan.(5)

6. Stuart, G.W., 2007. Buku Saku Keperawatan Jiwa (terjemahan). Edisi 5. Jakarta: Penerbit Buku kedokteran EGC(6)

7. Twonsend, M.C. 1998. Buku saku diagnosa keperawatan pada keperawatan psikiatri, Edisi 3, Jakarta : Penerbit Buku Kedokteran EGC.(7)

8. Nurgiyantoro, B. 2000. Statistik terapan untuk penelitian ilmu-ilmu Sosial, Yogyakarta : Gadjah Mada University Press.(8) gejala-gejala kekambuhan dan cara pencegahan kekambuhan sehingga apabila terjadi kekambuhan, keluarga dapat segera membawa pasien ke tempat pelayanan kesehatan.

9. Nursalam. 2003. Konsep \& penerapan metodologi penelitian ilmu keperawatan, Edisi 1, Penerbit : Salemba Medika.(9)

10. Handoko, R. 2006. Statistik kesehatan : belajar mudah tehnik analisis data dalam penelitian kesehatan, Edisi 1, Penerbit : Mitra cendikiaPress, yogyakarta(10)

11. Hidayat, A.A. 2003. Riset Keperawatan dan Tehnik Penulisan Ilmiah, edisi 1. Salemba Medika, Jakarta.(11)

12. Arikunto, S. 2002. Prosedur Penelitian suatu pendekatan praktek, Edisi 5, Penerbit PT Rineka Cipta, Jakarta.(12)

13. Depkes. 2003. Buku Pedoman Kesehatan Jiwa, cetakan I, Jakarta: Departemen Kesehatan RI Direktorat Jenderal Bina Kesehatan Masyarakat, Direktorat Kesehatan Jiwa Masyarakat.(13)

14. Kaplan I. H., Sadock P. B, 1997. Sinopsis Psikiatri Ilmu Pengetahuan prilaku Psikiatri

Klinis, edisi ke 7, Jilid 2, Binarupa Aksara, Jakarta(14)

15. Keliat, B.A. 1996. Peran serta keluarga dalam perawatan klien gangguan jiwa, Edisi 2, Jakarta : Penerbit Buku Kedokteran EGC.(15) 